Indonesian Journal of Islamic Communication, Vol. 1, No. 2, Desember 2018: 50-75

\title{
INTEGRASI KOMUNIKATIF PENDIDIKAN ISLAM MUHAMMAD IQBAL DAN HAMKA
}

\section{Zubaidah \\ Pascasarjana Universitas Nurul Jadid dan Yayasan Pasir al-Falah Probolinggo}

Diunggah 1 Oktober / Direvisi 23 November / Diterima 29 Desember 2018

\begin{abstract}
Abstrac: This research is a library research which examines the source of the data in the form of literature that related to the research problem. This research used qualitative approach. The data was obtained by analyzing the source of the data, so that the researcher used descriptive analysis method. Muhammad Iqbal in his taught in education suggests that education should be Islamic and dynamic, creative, and aimed to foster and give the opportunity to the spirit of creativity in every human being, besides to arm with the ability to master art, and new knowledge, intelligence and strength. However, Hamka suggest that education process is not only oriented on the material factors. That approach could not bring human being to the spiritual satisfaction. The form of harmony and integral education is the characteristic of ideal and effective Islamic education in order to obtain what we want, that is produced students that have good personality (insane kamil)
\end{abstract}

Keywords; Muhammad Iqbal, HAMKA, Integrasi, Komunikasi

Korespondensi: Zubaidah

Pascasarjana Universitas Nurul Jadid dan Yayasan Pasir al-Falah Probolinggo aida saja88@yahoo.com 


\section{A. PENDAHULUAN}

Sejarah mencatat bahwa dengan dilandasi semangat wahyu yang pertama, iqra', pendidikan Islam pada periode klasik telah mencapai derajat tertinggi. Intelektualisme menjadi ciri utama masyarakat muslim perkotaan pada periode tersebut. Pada masa periode klasik ini tidak ada masyarakat manusia yang memiliki etos keilmuan yang begitu tinggi seperti masyarakat muslim.

Mengapa kaum muslim tempo dulu mampu mencapai keberhasilan tersebut dan bagaimana cara menggapainya? Salah satu jawabnya adalah begitu dalamnya semangat keilmuan (spirit of science), dan ini menjadi kata kunci. Pada waktu itu, dengan semangat iqra' yang tinggi, sekelompok ilmuan muslim dan para sarjana dari kalangan muda dengan gigih menampung ilmu-ilmu keagamaan dan non keagamaan denga mendirikan lembaga-lembaga pendidikan. Secara spontan dan alamiah, lembaga-lembaga yang didirikan tersebut menyediakan situasi yang produktif bagi upaya pengembangan warisan Yunani dan bangsa Timur di bidang filsafat, teologi, matematika, kedokteran dan ilmu pengetahuan alam. Kaum muslim tersebut melakukan komunikasi dan interaksi dalam suasana belajar-mengajar yang tidak terikat. Pusat kegiatan pendidikan seperti ini marak di temui baik di istana, rumah seorang syaikh, toko buku, dan di rumah sakit atau di laboratorium perbintangan. Unsur terpenting dari system pendidikan informal ini adalah seorang syaikh, yang sambil duduk di atas kursi memimpin pertemuan dan menerima peserta didiknya yang duduk di lantai melingkarinya.

Menurut Johannes Pedersen, pendidikan dengan system seperti diatas telah melatih kaum muslim dalam menguasai ilmu pengetahuan. Para ilmuwan yang memiliki reputasi menonjol di bidangnya di beri kesempatan untuk mendemontrasikan hasil temuannya. Tradisi keilmuan seperti ini berlaku di seluruh dunia Islam. Mereka berhasil membentuk semacam ikatan persaudaraan yang dilandasi oleh semangat keilmuan yang tinggi, sekalipun masing-masing bergerak di bidang yang berlainan. Demikianlah, dengan semangat dan etos keilmuan yang tinggi dan melalu lembaga-lembaga pendidikan kaum muslim masa klasik berhasil menjadi khair ummah yang mampu mengungguli bangsa-bangsa lain dalam penguasaan ilmu pengetahuan dan teknologi ${ }^{1}$.

\footnotetext{
${ }^{1}$ Suyuthi Pulungan dalam Abdullah Idi, Revitalisasi Pendidikan Islam, (Yogyakarta, Tiara Wacana, 2006), x
} 


\section{Zubaidah}

Kini, pendidikan Islam seolah mengalami stagnasi, berjalan di tempat. Dalam diskursus perkembangan pemikiran Islam, berkembang berbagai isu ke permukaan tentang terjadinya akumulasi krisis pendidikan di dunia Islam. Sebagaimana dikemukakan oleh Ismail Raji al-Faruqi bahwa pendidikan di dunia Islam keadaannya sebagai yang terburuk, sehingga umat Islam menjadi sangat lemah ${ }^{2}$. Senada dengan al Faruqi, Khursid Ahmad mengemukakan bahwa diantara persoalan terbesar yang dihadapi dunia Islam dewasa ini adalah persoalan makin memburuknya pendidikan, padahal masa depan dunia Islam akan sangat bergantung kepada bagaimana kinerja dunia pendidikan ${ }^{3}$. Realitas ini menunjukkan bahwa pendidikan yang selama ini dilaksanakan oleh umat Islam ada yang "tidak beres", baik dari segi konsep maupun aktualitasnya.

Abu A'la al Maududi mengemukakan bahwa pendidikan di dunia Islam hanya dibangun atas romantisme masa lalu, tanpa memperhatikan realitas perkembangan modernitas masyarakat muslim, sehingga pendidikan di dunia Islam sangat stagnan dan tidak adaptif serta responsive dengan perkembangan masyarakat modern ${ }^{4}$. Fadlil al Jamali mengkritisi pendidikan Islam sebagai kurang menempatkan manusia sebagai subyek didik yang harus diberdayakan, manusia hanya dipandang sebagai obyek pendidikan semata ${ }^{5}$ Dengan kata lain kritik untuk menengarai lemahnya eksistensi system pendidikan dewasa ini antara lain : (1) Kurang memiliki relevansi dengan pembangunan yang menghasilkan tamatan yang canggung dan nganggur6, (2) Tidak relevannya pendidikan disebabkan adanya kesenjangan antara persediaan (supply) system dengan permintaan (demand) tenaga yang dibutuhkan berbagai sector. (3) Isi kurikulum kurang sesuai dengan perkembangan dan kemajuan IPTEK ${ }^{7}$

Apa yang harus kita lakukan? Dalam hal ini saya sependapat dengan Muhammad Iqbal dan HAMKA. Keduanya tidak secara tegas dikelompokkan oleh para ahli sebagai seorang ahli pendidikan, namun sesungguhnya keduanya banyak memaparkan konsep dan teori pendidikan yang relative original dan patut

\footnotetext{
2 Ismail Raji al Faruqi, Islamisasi Ilmu Pengetahuan: Prinsip-prinsip dan Rencana Kerja, terj.Anas Mahyudin, (Bandung, Pustaka, 1984), 12

${ }^{3}$ Machnun Husein, Pendidikan Islam dalam Lintasan Sejarah, (Yogyakarta, Nur Cahya, 1983), ix

${ }^{4}$ Abu A'la al Maududi, Manhaj Jadid I Tarbiyah wa Ta'lim, terj. Judi al Falasani, (Solo, CV Ramadani, 1991).

${ }^{5}$ Fadlil al Jamali, Menerobos Krisis Pendidikan Dunia Islam, terj.Muzayin Arifin, (Jakarta, Golden Terayon Press 1988)

${ }^{6}$ Fuad Amsari, Islam dalam Dimensi Pembangunan Nasional, (Surabaya, PT BIna Ilmu, 1989) 45

${ }^{7}$ HAR.Tilaan, Manajemen Pendidikan Nasional Kajian Pendidikan Masa Depan, (Bandung, PT Remaja

Rosdakarya, 1994), 152
} 
dikembangkan. Muhammad Iqbal dan HAMKA tidak hanya dapat digolongkan sebagai pemikir masalah pendidikan, tetapi juga sebagai praktisi pendidikan.

Muhammad Iqbal melakukan kritik terhadap system pendidikan Barat dan system pendidikan Islam. Menurut Iqbal, perlu dilakukan rekonstruksi terhadap pendidikan Islam sehingga didalamnya mampu mensintesakan hal-tal terbaik dari system pendidikan Barat dan juga dari system pendidikan Islam. Dalam rumusan Iqbal, sintesa dari system pendidikan Barat dan system pendidikan Timur ini disebutnya sebagai rekonstruksi pemikiran Islam.

Profesi HAMKA sebagai katib atau jurnalis secara langsung menempatkan sosok HAMKA sebagai pendidik, apalagi diantara karyanya tidak sedikit yang memuat pikiran-pikirannya dalam bidang pendidikan yang dilandasi oleh pemikirannya tentang manusia sebagai obyek sasaran pendidikan. Demikian juga dalam kapasitasnya sebagai praktisi pendidikan dijalaninya dalam kurun waktu yang sangat lama, yaitu diawali dengan aktivitasnya memimpin lembaga pendidikan bernama Tabligh School ${ }^{8}$ kemudian mendirikan dan memimpin lembaga pendidikan yang bernama Kulliyatul Muballighien di Padangpanjang9 . Aktivitas ini -sebagai pemikir dan praktisi pendidikan- dilakukan oleh HAMKA secara konsisten sampai akhir hayatnya, dengan menggunakan berbagai media pendidikan, seperti halaqah-halaqah, lembaga dakwah dan media massa.

Bertolak dari pernyataan-pernyataan diatas, peneliti tertarik mengadakan penelitian tentang rekonstruksi pendidikan dengan membandingkan antara pendidikan dalam pemikiran Muhammad Iqbal dan HAMKA. Penelitian ini merupakan library research (penelitian pustaka) dengan pendekatan kualitatif, melalui pengumpulkan buku-buku yang berkaitan dengan masalah penelitian yaitu konsep pendidikan Muhammad Iqbal dan HAMKA, kemudian membaca serta menelaah secara mendalam sehingga dapat diketahui secara jelas

\section{B. PEMBAHASAN}

\section{Pendidikan Islam perspektif Muhammad Iqbal}

\footnotetext{
8 Tabligh Scool merupakan lembaga pendidikan yang mencetak para kader dakwah Islamiyah. Tabligh School ini didirikan pada tahun 1929 dan dipimpin oleh HAMKA. Namun dketika HAMKA pindah ke Makassar (1931-1934) Tabligh School dihentikan, sebab pada saat itu di Padangpanjang reltif tidak ada tokoh yang dianggap representative menggnatikannya. Agus Hakim, Kulliyatul Mubalighien Muhammadiyah dan Buya HAMKA, Kenang-kenangan 70 Tahun Buya HAMKA, (Jakarta, Yayasan Nurul Islam, 1978), 46-64
} 
Secara tekstual Iqbal sebenarnya belum pernah menulis buku tentang teori atau filsafat pendidikan, apalagi membuat kurikulum pendidikan bagi kaum Muslim. Hasil pemikiran Iqbal mengenai pendidikan banyak tersirat dalam karyanya yang sebagian besar berbentuk puisi, sajak atau prosa. Sebagai filosof dan sekaligus seorang pujangga, Iqbal telah banyak meluangkan waktu dan perhatiannya terhadap persoalan-persoalan pendidikan. Dengan kata lain, seluruh pemikirannya secara kontekstual sesungguhnya telah mengisyaratkan perlunya dilakukan rekonstruksi di bidang pendidikan Islam. Melalui gubahan sajaksajaknya, Iqbal melakukan kritik terhadap system pendidikan yang berlaku pada saat itu ${ }^{10}$ Dalam salah satu sajaknya ia menulis:

Aku tamat dari sekolah dan pesantren penuh duka, Disitu tak kutemukan kehidupan

Tidak pula cinta

Tak kutemukan hikmah, dan tidak pula kebijaksanaan

Guru-guru sekolah adalah orang-orang yang tak punya nurani, Mati rasa, mati selera

Dan kyai-kyai adalah orang-orang yang tidak punya himmah, Lemah cita, miskin pengalaman ${ }^{11}$

Isi sajak tersebut merupakan kritikan Iqbal kepada system pendidikan Barat dan system pendidikan Islam tradisional. Iqbal memandang system pendidikan Barat lebih condong kepada materialisme, suatu kecenderungan yang nantinya merusak nilai-nilai spiritual manusia. Menurut Iqbal, pendidikan Barat hanya dapat mencetak manusia menjadi out put dengan memiliki intelektual tinggi, tetapi tanpa memiliki hati nurani yang berkualitas. Sistem pendidikan seperti itu pada akhirnya akan menyebabkan pertumbuhan dan perkembangan manusia tanpa keseimbangan antara aspek lahiriah dengan aspek batiniah ${ }^{12}$ Sementara itu pendidikan Islam tradisional dikritik Iqbal karena hanya memenjarakan otak dan jiwa manusia di dalam kurungan yang ketat. Dalam pandangan Iqbal, pendidikan tradisional tidak mampu mencetak manusia intelek yang dapat menyelesaikan berbagai persoalan keduniaan.

\footnotetext{
${ }^{10}$ Fazlur Rahman, Islam dan Modernitas: Tentang Transformasi Intelektual, alih bahasa Ahsin Mohammad, (Bandung, Pustaka, 1995), 66

${ }^{11}$ Abul Hasan al -Nadwi, Pendidikan Islam yang Mandiri, alih bahasa Afifi Muhammad, (Bandung, Dunia Ilmu, 1987), 33

${ }^{12}$ Abul Hasan al -Nadwi, Pendidikan Islam yang Mandiri, alih bahasa Afifi Muhammad, 34
} 
Dimata Iqbal, pendidikan adalah bagian tak terpisahkan dari peradaban manusia. Bahkan, pendidikan sekaligus menjadi substansi dari peradaban manusia ${ }^{13}$. Pendidikan bukan proses mengajar atau belajar semata karena kegiatan ini dianggap berlangsung secara sederhana atau mekanistis, dan hanya berlangsung diantara empat dinding sekolah. Pendidikan dalam pengertian sempit ini tidak mampu mencakup pembinaan yang dapat membentuk, mengembangkan dan memodifikasi gagasan dan perbuatan perorangan atau kelompok. Iqbal berpendapat bahwa pendidikan harus dipandang sebagai suatu keseluruhan daya budaya yang mempengaruhi kehidupan perorangan maupun kelompok masyarakat ${ }^{14}$ Oleh karenanya, lanjut Iqbal, pendidikan sesungguhnya bertujuan untuk membentuk "manusia" sejati/sempurna/insan kamil 15.

Pandangan Iqbal tentang manusia sejati/sempurna/insan kamil tergambar dalam pendapatnya yang menyatakan bahwasanya untuk mengenal Tuhan hanya berpusat pada dirinya sendiri, mengenal diri sebaik-baiknya, dan untuk menyempurnakan diri bagi Iqbal harus menciptakan sifat-sifat ketuhanan di dalam diri agar dapat berperilaku seperti perilaku Tuhan ${ }^{16}$. Cara penciptaan sifatsifat Tuhan tidak merenung-renung sifat Tuhan kemudian masuk pada esensi yang mutlak seperti yang dilakukan al-Jilli17 ${ }^{17}$, tetapi usaha yang gigih dengan menyerap sifat-sifat Tuhan ke dalam dirinya, hal ini sesuai dengan semboyan Iqbal "Takhallaqu bi Akhlaqillah" (berperangailah dengan perangai Tuhan). Jika perangai Tuhan telah terserap keseluruhannya berarti telah terjadi persatuan antara diri dan Tuhan (kata Iqbal bagi Tuhan laku, pikir dan penciptaan adalah identik). Karena manusia berpusat pada diri sendiri menyerap Tuhan bukan berarti manusia hanyut ke dalam Tuhan, tetapi Tuhanlah yang hanyut ke dalam manusia. Kalau manusia hanyut ke dalam Tuhan, kata Iqbal berarti hilang kepribadiannya. Perangai/akhlak yang dimaksudkan adalah akhlak Allah yang mahasempurna, yakni akhlak yang tertuang dalam asma al-husnaNya. Asma-asma

\footnotetext{
13 Salahuddin al-Nadwi, Muhammad Iqbal wa Qadaya al-Tajdid, (Studia Islamika, Vol.II. No.I, 1995) 171

14 KG.Saiyidain, Iqball's Eductioon Philosophy (Percikan Filsafat Iqbal Mengenai Pendidikan), alih Bahasa MI Soelaeman, (Bandung, CV Diponegoro, 1981), 20

15 Fazlur Rahman, Islam dan Modernitas: Tentang Transformasi Intelektual, alih bahasa Ahsin Mohammad, (Bandung, Pustaka, 1995), 67

16 Danusiri, Epistemologi dalam Tasawuf Iqbal, (Yogyakarta, Pustaka Pelajar, 1996), 134

17 Muh.Iqbal, The Development of Metaphysucs in Persia: A Contribution to The History of Muslim Philosophy (Metafisikan Persia Suatu Sumbangan Untuk Sejarah Filsfat Islam).diterjemahkan Jobar Ayoeb, (Bandung, Mizan, 1995), 110
} 
itu sedapat-dapatnya diinternalisasikan dalam kehidupan manusia sebatas kemampuan kemanusiaannya.

Posisi manusia sejati/sempurna/insan kamil versi Muhammad Iqbal ialah transendentalisme yaitu ada perbedaan tajam antara manusia dengan Tuhan khalik dan makhluk ${ }^{18}$. Iqbal juga mengemukakan tentang ciri-ciri manusia sejati/sempurna/insan kamil yaitu:

1) Manusia yang telah dilengkapi oleh Tuhan dengan beragai daya tangkap seperti serapan indera, rasio dan intuisi dalam kadar yang sangat tinggi oleh karena dapat merebut masa dan ruang, menguasai dunia. Dengan potensi itu manusia utama dapat menempuh kearah Tuhan mengenali diri dengan ketuhanan dan mengenali Tuhan cahaya diri

2) Manusia adalah teman kerja Tuhan di bumi, seperti yang dimuat dalam sajaknya:

Ku-mohonkan dari karunia-Mu sebagai kawan Seorang murid dirahasia-rahasia alam semester Seorang kawan penuh kegilaan dan khidmad Seorang yang tak tahu penjelmaan hal-hal kosong Agar dapat kupercayakan keluhnya kepada jiwanya Dan melihat kembali wajahku di dalam kalbunya Bayangnya hendak kubentuk dari tanah lempungku sendiri ${ }^{19}$

Dari sajak diatas terlihat bahwa hubungan teman karib itu sangat dinamis. Dengan potensi masing-masing kedua belah pihak mencipta secara dialektik. Menurut Iqbal ciptaan Tuhan belum selesai, baru terwujud setengah jadi dan manusia yang bertugas mengolahnya menjadi barang konsumtif, seperti yang termaktub dalam sajak berikut ini:

Kau ciptakan malam dan aku yang membuat lampu Kau menciptakan tanah liat dan aku yang membuat piala Kau menciptakan sahara dan gunung-gunung dan belantara Kau menciptakan kebun anggur, taman-taman padang tanaman ${ }^{20}$

${ }^{18}$ Danusiri, Epistemologi dalam Tasawuf Iqbal, (Yogyakarta, Pustaka Pelajar, 1996), 136

${ }^{19}$ Muhammad Iqbal, Javid Namah, diterj. Dr.Mohammad Sadikin, (Jakarta, Pustaka Panti Mas, 1987), 34

20 Miss Luce-Calude Maitre, Pengantar ke Pemikiran Iqbal, alih bahasa Djohan Efendi, (Bandung, Mizan, 1992), 32 
Ringkasnya insan kamil sebagai teman kerja Tuhan kadang-kadang nampak terlibat dalam perundingan untuk mencipta suatu model tertentu.

3). Irada manusia utama adalah seiradah dengan Tuhan, seperti yang telah diungkapkan oleh Iqbal bahwa dalam kemauannya, iradah Tuhan hilang didalamnya ${ }^{21}$

4). Ilmu dan kekuasaan Tuhan menjadi kembar dengan ilmu dan kekuasaan manusia utama, senada dengan apa yang dikatakannya bahwa ilmuNya kembar dengan kodrat manusia utama

5). Insan kamil adalah orang yang tak terkendali oleh qada' dan qadar, melainkan mampu mengarahkannya kemana harus terjadi, "Padi dan sore si budak terikat dan kata qadha terucapkan pada qadar dan peristiwa zaman kedua telapak tangan si bebas melukis dan mengarahkannya" 22

Ciri-ciri manusia sejati/sempurna yang diutarakan Iqbal mirip dengan yang disampaikan oleh Ahmad Tafsir yang menyebutkan manusia sejati/sempurna menurut Islam yaitu: (1) Jasmani yang sehat serta kuat dan berketarampilan, (2) Cerdas serta pandai, (3) Rohani yang berkualitas tinggi 23

Namun perlu diperhatikan bahwa manusia sejati/sempurna/insane kamil tidak akan terwujud hingga ego melampui proses yang mencakup tiga tahap, yaitu: (1) Ketaatan pada hukum, (2) Penguasaan diri sendiri yang merupakan bentuk tettinggi, kesadaran diri tentang pribadi, dan (3) Kekhalifahan Ilahi

"Naib atau manusia sejati/sempurna/insane kamil adalah khalifah Tuhan di muka bumi. Ia merupakan ego yang paling sempurna, puncak kehidupan, menal maupun keharmonisan. Kemampuan tertinggi bersaatu dalam dirinya menjadi pengetahuan tertinggi. Dalam dirinya pikiran dan perbuatan, naluri dan nalar menjadi satu. Ia adalah buah terakhir dari pohon kemanusiaan dibenarkan, sebab ia dating di saat terakhir. Ia adalah penguasa umat manusia yang sebenarnya; kerajaannya adalah kerajaan Tuhan di muka bumi"24

Dalam versi lain, Muhammad Iqbal, yang dikutip oleh Dawan Rahardjo ${ }^{25}$, memberikan criteria insan kamil dengan criteria insan yang beriman yang didalam

\footnotetext{
${ }^{21}$ Danusiri, Epistemologi dalam Tasawuf Iqbal, (Yogyakarta, Pustaka Pelajar, 1996), 139

${ }^{22}$ Abdul Wahab 'Azzam, Iqbal: Siratuh wa Falsafatuh wa Syi'ruh (Filsafat dan Puisi Iqbal), diterjemahkan oleh Ahmad Rofi' Usman, (bandung, Pustaka Husna, tt), 175

${ }^{23}$ Ahmad Tafsur, Ilmu Pendidikan dalam Perspektif Islam, (Bandung, Remaja Rosdakarya, 1992), 41

24 Muhammad Iqbal, Javid Namah, diterj. Dr.Mohammad Sadikin, (Jakarta, Pustaka Panti Mas, 1987), 35

25 Dawan Rahardjo (peny), Insan Kamil: Konsep Manusia menurut Islam, (Jakarta, Temprint, 1989), 26
} 


\section{Zubaidah}

dirinya terdapat kekuatan, wawasan, perbuatan, dan kebijaksanaan dan mempunyai sifat-sifat yang tercermin dalam pribadi Nabi saw, berupa akhlakul karimah. Tahapan untuik mencapai insal kamil itu diperoleh melalui ketaatan terhadap hokum-hukum Allah, penguasaan ini sebagai bentuk tertinggi kesadaran diri tentang pribadi dan kekhalifahan Ilahi.

Pendapat Muhammad Iqbal tentang tujuan pendidikan diatas hampir sama dengan pendapat beberapa cendekiawan muslim, karena mereka sepakat bahwa tujuan pendidikan ialah pembentukan pribadi muslim yang sejati/sempurna sebagai khalifat Allah di muka bumi, yang beriman dan beramal shaleh serta bahagia di dunia dan akhirat. Menurut al Ghazali, yang dikutip oleh Fathiyah Hasan Sulaiman ${ }^{26}$, tujuan umum pendidikan tercermin dalam dua segi yaitu (1) insan purna yang bertujuan mendekatkan diri kepada Allah swt, dan (2) insan purna yang bertujuan mendapatkan kebahagiaan hidup di dunia dan di akhirat. Kebahagiaan dunia akhirat dalam pandangan al-Ghazali adalah menempatkan kebahagiaan dalam proporsi yang sebenarnya. Kebahagiaan yang lebih memiliki nilai universal, abadi dan lebih hakiki itulah yang diprioritaskan

Ibnu Khaldun, yang dikutip oleh Muhammad Athiyah al Abrasyu merumuskan tujuan pendidikan dengan berppijak pada firman Allah dalam QS.alQashas: 77 yang berbunyi:

"Dan carilah pada apa yang telah dianugerahkan Allah kepadamu (kebahagiaan) negeri akhirat, dan janganlah kamu lupa bagian dari (kenikmatan) duniawi"

Berdasarkan Firman itu, Ibnu Khaldun merumuskan bahwa tujuan pendidikan Islam terbagi atas dua macam, yaitu (1) tujuan yang berorientasi ukhrawi, yaitu membentuk seorang hamba agar melakukan kewajiban kepada Allah, (2) Tujuan yang berorientasi duniawi, yaitu membentuk manusia mampu menghadapi segala bentuk kebutuhan dan tantangan kehidupan, agar hidupnya lebih layak dan bermanfaat bagi orang lain.

Muhammad Fadhil al-Jamali merumuskan tujuan pendidikan dengan empat macam, yaitu: (1) mengenalkan manusia akan peranannya diantara sesama

26 Fathiyah Hasan Sulaiman, Sistem Pendidikan Versi al-Ghazali. terj. Fathur Rahman, (Bandung, al-Ma'arif, 1986), 24 
titah makhluk dan tanggung jawabnya di dalam hidup ini, (2) mengenalkan manusia akan interaksi social dan tanggung jawabnya dalam tata hidup bermasyarakat, (3) mengenalkan manusia akan alam dan mengajak mereka untuk mengetahui hikmah diciptakannya serta memberi kemungkinan kepada mereka untuk mengambil manfaat darinya, (4) mengenalkan manusia akan pencipta alam (Allah) dan menyuruhnya beribadah kepadaNya ${ }^{27}$

Rumusan tujuan pendidikan yang dihasilkan dari seminar pendidikan Islam sedunia tahun 1980 di Islamabad adalah: Pendidikan seharusnya bertujuan mencapai pertumbuhan yang seimbang dalam kepribadian manusia secara totall melalui pelatihan spiritual, kecerdasan, rasio, perasaan, dan panca indra. Oleh karena itu, pendidikan seharusnya pelayanan bagi pertumbuhan manusia dalam segala aspeknya yang meliputi aspek spiritual, intelektual, imajinasi, fisik, ilmiah, linguistic, baik secara individu, maupun secara kolektif dan memotivasi semua aspek tersebut kea rah kebaikan dan pencapaian kesempurnaan. Tujuan utama pendidikan bertumpu pada terealisasinya ketundukan kepada Allah swt baik dalam level individu, komunitas dan manusia secara luas. ${ }^{28}$

\section{Pendidikan Islam perspektif HAMKA}

Secara teknis ada beberapa istilah yang terkait dan berhubungan dengan persoalan pendidikan Islam. Hasan Langgulung ${ }^{29}$ menyebutkan 3 istilah yang sama maknanya dengan kata pendidikan yaitu $t a^{\prime} l i m$, $t a^{\prime} d i b$ dan tarbiyah. Katakata dimaksud akan terlihat dalam ayat berikut ini:

Kata ta'lim tersirat dari firman Allah QS al Baqarah, $2: 31$

"Dan Allah mengajarkan kepada Adam segala nama, kemudian Ia berkata kepada malaikat:: beritahulah akau nama-nama semua itu jika kamu benar"

Kata tarbiyah akan terlihat dalam firman Allah pada surat Bani Israil, 17:24

"Dan rendahkanlah dirimu terhadap mereka berdua dengan penuh kesayangan dan ucapkanlah:: "Wahai Tuhanku, kasihilah mereka keduanya, sebagaimana mereka berdua telah mendidik aku waktu kecil"

\footnotetext{
27 Muhammad Fadhil al-Jamali, Filsafat Pendidikan dalam al-Qur'an,terj. Judial Falasani, (Surabaya, Bina Ilmu, 1986), 3

28 Arifin HM, Kapita Selekta Pendidikan Islam dan Umum, (Jakarta, Bina Aksara, 1991), 4

${ }^{29}$ Hasan Langgulung, Azas-azas Pendidikan Islam, (Jakarta, Radar Jaya Ofsett, 1987), 4
} 


\section{Zubaidah}

Kata $t a^{\prime} d i b$ akan terlihat dari hadis Rasulullah saw yang berbunyi:

"Allah mendidikku, maka Ia memberikan kepadaku sebaik-baiknya pendidikan"

Sekalipun ketiga istilah diatas sama-sama dapat diartikan dengan pendidikan, namun ketiganya mengandung perbedaan yang sangat tajam. Menurut Naquib al-Attas ${ }^{30}$ kata ta'lim lebih sempit maknanya dibandingkan dengan kata tarbiyah dan ta'dib. Ta'lim lebih menitikberatkan pada aspek pengajaran. Dengan demikian ta'lim hanya menjadi bagian dari pelaksanan pendidikan. Sedangkan kata tarbiyah, di Negara-negara yang menggunakan bahasa Arab, maknanya terlalu luas. Kata ini dapat digunakan untuk binatang dan tumbuh-tumbuhan dengan pengertian memelihara atau membela, menternak dan lain-lain. Naquib lebih setuju menggunakan kata $t a^{\prime} d i b$ untuk menjadi istilah pendidikan Islam, sebab dengan kata $t a^{\prime} d i b$, manusialah yang berhak memperoleh pendidikan. Kata ini dianggap tidak terlalu luas seperti tarbiyah, namun juga sekaligus tidak terlalu sempit seperti terlihat dari makna ta'lim. Kata ta'dib telah menjadi kompromi antara apa yang yang dibutuhkan dari kata ta'lim dan dari kata tarbiyah.

Pendapat sama disampaikan oleh Jusuf Amir Feisal. Ia mengatakan bahwa dalam tradisi Islam terdapat tiga istilah yang sering digunakan untuk menyebut pendidikan Islam. Ketiga istilah dimaksud adalah ta'lim, tarbiyah dan ta'dib. Dari ketiga istilah itu kata yang paling cocok untuk menyebut pendidikan Islam ialah ta'dib. Kata ini menjadi kompromi atas makna yang terdapat dalam kata tarbiyah (yang maknanya amat luas) dan makna yang terkandung dalam kata ta'lim (yang maknanya teramat sempit)

Namun HAMKA melalui karya-karyanya hanya menyebutkan dua istilah yaitu ta'lim dan tarbiyah. Berikut penjelasan HAMKA tentang kedua kata tersebut:

- Ta'lim

HAMKA merujuk penggunaan kata ta'lim pada QS 2: 31. Dalam tarsirnya, ia mengatakan bahwa pengertian ta'lim pada ayat tersebut mengandung makna, bahwa "Pendidikan merupakan proses pentransferan seperangkat pengetahuan

${ }^{30}$ Naquib al-Attas, Islam dan Sekularisme, (Bandung, Pustaka Setia, 1980), 211 
yang dianugerahkan Allah kepada manusia (Adam)". Dengan kekuatan yang dimilikinya, baik kekuatan pancaindera maupun akal, peserta didik dituntut untuk menguasai materi yang ditransfer. Kekuatan tersebut berkembang secara bertahap dari yang sederhana kea rah yang lebih baik. Dengan kekuatan ini pula peserta didik dapat melaksanakan fungsinya sebagai pemegang amanat Allah, sekaligus membongkar rahasia alam bagi kemaslahatan seluruh alam semesta. Pandangannya tersebut diperkuat dengan merujuk pada QS 10 : 5

"Dialah yang menjadikan matahari bersinar dan bulan bercahaya. Dan ditetapkannya manzilah-manzilah (tempat-tempat) bagi perjalanan bulan itu, supaya kalian mengetahui bilangan tahun dan perhtungan waktu. Allah tidak menciptakan yang sedemikian itu melainkan dengan hak. Dia menjelaskan tanda-tanda (kebesaran-Nya) kepada orang-orang yang mengetahui"

Firman Allah QS 10: 5 tersebut menurut HAMKA merupakan motivator bagi peserta didik untuk menggunakan potensi yang dimiliki guna lebih mengenal alam semesta yang terdapat dalam susunan tata surya. Dalam ayat tersebut Allah menjelaskan bagaimana seluruh makhluk berjalan menurut ketentuan yang telah ditetapkanNya. Kesemua ini merupakan panduan kepada peserta didik untuk melakukan serangkaian penelitian guna menyingkap rahasia Allah. Untuk sampai pada predikat ya'lamuun, peserta didik di tuntut untuk menggabungkan seluruh potensinya, baik perasaan (iman), akal, dan pancaindera. Melalui gabungan potensi yang dimilikinya, peserta didik akan lebih mudah memahami fenomena yang ada. Dengan menyingkap rahasia tata surya, pada gilirannya peserta didik akan dapat menciptakan ilmu-ilmu lain yang erat hubungannya bagi kehidupan. Ilmu-ilmu ini antara lain adalah Ilmu Berhitung, Ilmu Falak dan Ilmu Hisab.

Kata ta'lim dapat diartikan sebagai suatu proses terus menerus yang diusahakan manusia semenjak lahir (QS.16: 78), sampai manusia tua renta atau bahkan meninggal dunia (QS.22: 5). Menurutnya proses manusia mengembangkan potensinya dilakukanmelalui pendidikan. Proses ini dimulai sejak manusia lahir sampai perkembangannya mengalami kefakuman, yaitu dengan adanya kematian. HAMKA memahami kata ta'lim sebagai proses pendidikan dan bukan pada hakikat pendidikan. Padahal wacana pendidikan Islam bukan hanya sebatas proses, akan tetapi meliputi bentuk materi berikut nilai yang ada didalamnya, aspek penekanan 


\section{Zubaidah}

yang diinginkan, pendidik, peserta didik, lingkungan dimana pendidikan itu dilaksanakan dan tujuan yang ingin dicapai.

\section{- Tarbiyah}

Untuk term tarbiyah, bila dihubungkan dengan bentuk madhinya yang tertera dalam QS.17: 24 disebutkan "kamaa rabbayaanii shaghiraa,sebagaimana menddikku sewaktu kecil "dan bentuk mudhari'nya yang tertera ala QS 26: 18 disebutkan "alam nurabbika fina waliida, bukankah kami telah mengasuhmu diantara (keluarga) kami"dan QS 2: 276, maka menurut HAMKA, kata tarbiyah memiliki arti mengasah, bertanggungjawab, memberi makan, mengembangkan, memelihara, membesarkan, menumbuhkan, memproduksi, dan menjinakkannya, baik yang mencakup aspek jasmaniah maupun rohaniyah. Penekanannya dalam memahami makna "memelihara" dalam kata tarbiyah sebagai "perbuatan pemeliharaan yang dilakukan kedua orang tua terhadap anaknya. Proses ini dilakukan dengan sabar dan penuh kasih sayang guna membantu anak dari ketidak berdayaannya sampai ia mampu mandiri, baik secara fisik maupun psikis".

Menurut HAMKA, penggunaan kata rabb atau tarbiyah dari QS.9: 129; QS.13 :16 dan QS 113: 1 dapat diartikan "pemelihara" dan "pelindung". Pemeliharaan tersebut mencakup pada pemeliharaan semua ciptaan Allah yang ada di muka bumi, tanpa terkecuali sesama manusia. Penekanannya lebih memuat pesan nilai akhlak, baik secara vertical maupun horizontal. Hal ini dapat dilihat ketika Allah memerintahkan Rasulullah untuk menanyakan kepada kaum kafir -setelah mereka memikirkan dan merenungkan- tentang zat yang memelihara alam semesta. Jawabannya jelas bahwa semua itu diciptakan dan dipelihara oleh Allah swt.

Dari penjelasan diatas, terlihat bahwa dalam memposisikan pendidikan sebagai proses, HAMKA cenderung menggunakan kata ta'lim. Sementara alam melihat pendidikan sebagai transmisi nilai dan misi tertentu, ia kelihatannya lebih cenderung menggunakan kata tarbiyah. Pendekatan yang dilakukan kelihatannya sebagai upaya mengintegralkan makna kedua kata tersebut dalam sebuah kerangka berfikir yang harmonis.

Menurut penulis, pendekatan yang dilakukan HAMKA merupakan bentuk kehati-hatiannya dalam menafsirkan ajaran Islam, sekaligus sebagai upaya yang 
cukup bijaksana. HAMKA terkesan tidak ingin terjebak dalam perdebatan makna kata, akan tetapi lebih menekankan pada esensi yang dikandung oleh kata tersebut. Persoalan ini dapat dimaklumi karena kedua kata tersebut sama-sama disinyalir Allah dalam al-Qur'an dan mengandung sisi-sisi pendidikan. Hanya saja yang membedakan keduanya adalah pada perbedaan penekanan. Namun demikian, ta'lim dan tarbiyah memiliki keterkaitan dan saling melengkapi antara satu dengan yang lain.

Tanpa mengenyampingkan berbagai pendapat tentang kata mana yang lebih mewakili dalam memaknai pengertian pendidikan Islam, akan tetapi penulis bermaksud untuk lebih menyederhanakan persoalan, maka penulis cenderung menggunakan kata tarbiyah untuk pendidikan Islam, karena kata tarbiyah mengandung arti yang lebih komprehensif dalam memaknai pendidikan Islam, baik vertical maupun horizontal. Prosesnya merujuk pada pemeliharaan dan pengembangan seluruh potensi (fitrah) peserta didik, baik jasmaniah maupun rohaniah. Penulis sangat sependapat dengan Mushthafa al-Maraghi dan Ismail Haqi al-Barusawi,dimana pendapat Mushthafa al Maraghi ${ }^{31}$ yang membagi aktivitas al-tarbiyah dengan dua macam: (1) Tarbiyah khalqiyyah, yaitu pendidikan yang terkait dengan pertumbuhan jasmaniah.agar dapat dijadikan sebagai sarana dalam pengembangan rohaninya, (2) Tarbiyah diniyyah tahdzibiyyah, yaitu pendidikan yang terkait dengan pembinaan dan pengembangan akhlak dan agama manusia, untuk kelestarian rohaninya. Pemetaan dalam pengertian tarbiyah ini menunjukkan bahwa pendidikan Islam tidak sekedar menitikberatkan pada kebutuhan jasmani, tetapi diperlukan juga pengembangan kebutuhan psikis, social, etika dan agama untuk kebahagiaan dunia dan akhirat. Hal itu mengandung arti bahwa pengembangan kreativitas peserta didik tidak boleh bertentangan dengan etika ilahiyah yang telah ditetapkan didalam kitab suci. Sementara pendapat Ismail Haqi al Barusawi ${ }^{32}$ dalam klasifikasi yang berbeda membagi tarbiyah pada aspek sasarannya: (1) Kepada manusia, sebagai makhluk yang memiliki potensi rohani, maka tarbiyah diartikan dengan proses pemberian nafsu dengan berbagai kenikmatan,

\footnotetext{
${ }^{31}$ Mushthafa al-Maraghi, dalam Abdul Mujib, Ilmu Pendidikan Islam, (Jakarta, Kencana Prenada Media, 2006), 17

32 Ismail Haqi al-Barusawi dalam Abdul Mujib, Ilmu Pendidikan Islam, (Jakarta, Kencana Prenada Media, 2006), 17
} 


\section{Zubaidah}

pemeliharaan hati nurani dengan berbagai kasih saying, bimbingan jiwa dengan hokum-hukum syariah, pengarahan hati nurani dengan berbagai etika kehidupan, dan penerangan rahasia hati dengan hakikat pelita, (2) Kepada alam semesta, yang tidak memiliki potensi rohani. Maka tarbiyah diartikan dengan pemeliharaan pemenuhan segala yang dibutuhkan serta menjaga sebab-sebab yang menjadikan eksistensinya.

HAMKA membedakan makna pengajaran dan pendidikan. Pengajaran ialah upaya untuk mengisi intelektual peserta didik dengan sejumlah ilmu pengetahuan, sedangkan pendidikan merupakan serangkaian upaya yang dilakukan pendidik untuk membantu membentuk watak, budi, akhlak, dan kepribadian peserta didik, sehingga ia tahu membedakan mana yang baik dan mana yang buruk. Dalam mendefinisikan pendidikan dan pengajaran, HAMKA membedakannya hanya dari pengertian kata; akan tetapi secara esensial ia tidak membedakannya. Kedua kata itu merupakan suatu system yang saling berkaitan. Setiap proses pengajaran tidak akan banyak berarti bila tidak dibarengi dengan proses pendidikan ; demikian pula sebaliknya didalam proses pendidikan terdapat proses pengajaran. Keduanya saling melengkapi satu sama lain, dalam rangka mencapai tujuan yang sama. Tujuan dan misi pendidikan akan tercapai melalui proses pengajaran. Dengan pertautan kedua proses ini, peserta didik akan memperoleh kemuliaan hidup, baik di dunia maupun di akhirat.

Definisi diatas merupakan salah satu titik perbedaan pendapat HAMKA tentang batasan pendidikan yang dewasa ini yang secara parsial mendikotomikan kedua istilah tersebut. HAMKA mencoba membangun proses pengajaran dan pendidikan dalam sebuah konstruksi yang integral. Proses pendidikan tidak hanya berorientasi pada hal-hal yang bersifat material belaka. Pendekatan yang demikian itu tidak akan dapat membawa manusia kepada kepuasan batin. Pendidikan yang baik ialah pendidikan yang dapat mengintegralkan potensi fitrahNya yang tinggi dengan potensi akal pikiran, perasaan dan sifat-sifat kemanusiaannya yang lain secara serasi dan seimbang; dimana melalui integrasi kedua unsure potensi tersebut, maka peserta didik akan mampu mengetahui rahasia yang tertulis didalam al-Qur'an dan Hadis dan fenomena alam semesta yang tak tertulis (QS.35: 28). Melalui pendekatan ini peserta didik akan dapat 
menyingkap rahasia keagungan dan kebesaranNya, sekaligus untuk mempertebal keimanannya kepada Allah.

Setiap tindakan dan aktivitas harus berorientasi pada tujuan atau rencana yang telah ditetapkan. Pendidikan seharusnya berorientasi pada tujuan yang ingin dicapai, bukan semata-mata berorientasi pada sederetan materi; karena itulah tujuan menjadi komponen pendidikan yang harus dirumuskan terlebih dahulu sebelum merumuskan komponen-komponen pendidikan yang lain.

Tujuan merupakan standar usaha yang dapat ditentukan, serta mengarahkan usaha yang akan dilalui dan merupakan titik pangkal untuk mencapai tujuan-tujuan lain. Disamping itu, tujuan dapat membatasi ruang gerak usaha, agar kegiatan dapat terfokus pada apa yang dicita-citakan, dan yang terpenting lagi adalah dapat memberi penilaian atau evaluasi pada usaha-usaha pendidikan $^{33}$ HAMKA juga berpendapat bahwa setiap upaya manusia dalam melaksanakan berbagai aspek kehidupan, termasuk aspek pendidikan, harus ada ghoyah (tujuan) dan wasilah (metode). Ghoyah adalah pernyataan tujuan yang akan diwujudkan, sedangkan wasilah adalah metode atau cara yang akan dilakukan untuk mewujudkan tujuan tersebut.

Pendidikan merupakan aktivitas yang sistematis dan terencana dalam rangka memenuhi tujuan hidup manusia, yaitu secara horizontal sebagai khalifah Allah fi al-Ardl dan secara vertical sebagai Abd.al Allah ${ }^{34}$. Disamping itu, pendidikan bertujuan untuk mewujudkan kesempurnaan diri (al-kamil) dan keutamaan budi ${ }^{35}$ yang dengannya seseorang akan memperoleh kebahagiaan (al-sa'adah) ${ }^{36}$.

\section{Komparasi pemikiran Muhammad Iqbal dan HAMKA terntang pendidikan}

\section{Islam}

Muhammad Iqbal memandang bahwa tujuan akhir pendidikan adalah membina individualitas menjadi suatu pribadi yang mantap yang hanya dapat merealisasikan dirinya dalam gairah hidup yang meluap penuh aktivitas. Tujuan akhir pendidikan bukan sekedar kegiatan intelektual, melainkan tindakan yang memperdalam keseluruhannya, keberadaan ego dan mempertegas serta mempertajam kemauannya, disertai keyakinan yang kreatif bahwa dunia ini

\footnotetext{
33 Ahmad D Marimba, Pengantar Filsafat Pendidikan, (Bandung, al-Ma'arif, 1989), 45

${ }^{34}$ HAMKA, Lembaga Hidup, (Jakarta, Pustaka Panjimas, 1997), 190

35 HAMKA, Lembaga Budi, (Jakarta, Pustaka Panjimas, 1983), 2

36 HAMKA, Lembaga Hidup, (Jakarta, Pustaka Panjimas, 1983), 192
} 


\section{Zubaidah}

bukan sesuatu yang sekedar cukup dilihat, dikenal melalui berbagai konsep pandangan tertentu, melainkan sesuatu yang harus diciptakan dan dibuat kembali melalui kegiatan dan aktivitas yang berkesinambungan. Dengan lain perkataan bahwa tujuan pendidikan adalah terbentuknya insan kamil (manusia sempurna) yang muncul dari pencarian yang penuh semangat.

Manusia sempurna (insan kamil) akan terwujud melalui proses yang mencakup tiga tahap, yakni ketaatan pada hukum, penguasaan diri sendiri yang merupakan bentuk tertinggi kesadaran diri tentang pribadi, dan kekhalifahan Ilahi. Disamping itu, Muhammad Iqbal menyatakan bahwa untuk mengenal Tuhan hanya berpusat pada dirinya sendiri, mengenal diri sebaik-baiknya, dan untuk menyempurnakan harus menciptakan sifat-sifat ketuhanannya di dalam diri agar dapat berperilaku seperti perilaku Tuhan ${ }^{37}$ Cara penciptaan sifat-sifat Tuhan tidak merenung-renung sifat Tuhan kemudian masuk pada esensi nan mutlak seperti yang dilakukan al-Jilli ${ }^{38}$, tetapi usaha yang gigih dengan menyerap sifat-sifat Tuhan ke dalam dirinya, yakni Takhallaqu bi Akhlaqillah (berperangailah dengan perangai Tuhan). Jika perangai Tuhan telah terserap keseluruhannya berarti telah terjadi persatuan antara diri dan Tuhan (kata Iqbal bagi Tuhan, laku, pikir dan penciptaan adalah identik).

HAMKA sependapat dengan Muhammad Iqbal tentang tujuan akhir pendidikan. Dengan redaksi yang berbeda, beliau mengatakan bahwa tujuan akhir dari pendidikan ialah kesempurnaan diri (al-kamal) dan keutamaan budi sehingga dapat memperoleh kebahagiaan sejati.

Kebahagiaan itu tidaklah diukur dengan terpenuhinya kebutuhan manusia yang bersifat biologis-materialistis, hal ini berdasar realita empiric bahwa dalam kehidupan sehari-hari terdapat individu yang memiliki kemampuan memenuhi kebutuhan biologis-materialistik, tetapi justru nampak tidak bahagia, karena itu kebahagiaan bukanlah berasal dari luar diri tapi dalam diri seseorang yaitu terpenuhinya kebutuhan mental spiritual ${ }^{39}$. Kebahagiaan yang dimakudkan beliau adalah kebahagiaan yang seimbang antara aspek ukhrawi (mental spiritual) dan

\footnotetext{
${ }^{77}$ Danusiri, Epistemologi dalam Tasawuf Iqbal, (Yogyakarta, Pustaka Pelajar, 1996), 134

${ }^{8}$ Muh.Iqbal, The Development of Metaphysucs in Persia: A Contribution to The History of Muslim Philosophy (Metafisikan Persia Suatu Sumbangan Untuk Sejarah Filsfat Islam).diterjemahkan Jobar Ayoeb, (Bandung, Mizan, 1995), 110

39 HAMKA, Filafat Hidup., 88
} 
aspek duniawi (fisik-material), atau dengan bahasa yang biasa digunakan HAMKA adalah kebahagiaan lahir dan batin.

Pendapat Muhammad Iqbal dan HAMKA tentang tujuan akhir pendidikan intinya sama yaitu membentuk manusia sempurna yang senantiasa memiliki kebahagiaan yang sempurna tidak hanya di dunia tapi juga di akhirat. Iqbal melihat, insan kamil dicapai melalui beberapa proses. Pertama, ketaatan pada hukum; kedua penguasaan diri sebagai bentuk tertinggi kesadaran diri tentang pribadi; dan ketiga kekhalifahan Ilahi.

Pendapat Muhammad Iqbal dan HAMKA tentang tujuan pendidikan diatas hampir sama dengan pendapat beberapa cendekiawan muslim, karena mereka sepakat bahwa tujuan pendidikan ialah pembentukan pribadi muslim yang sejati/sempurna sebagai khalifat Allah di muka bumi, yang beriman dan beramal shaleh serta bahagia di dunia dan akhirat. Menurut al Ghazali, yang dikutip oleh Fathiyah Hasan Sulaiman ${ }^{40}$, tujuan umum pendidikan tercermin dalam dua segi yaitu (1) insan purna yang bertujuan mendekatkan diri kepada Allah swt, dan (2) insan purna yang bertujuan mendapatkan kebahagiaan hidup di dunia dan di akhirat.

Tidak ada perbedaan antara pemikiran Muhammad Iqbal dan HAMKA tentang peserta didik. Menurut HAMKA anak merupakan bunga hidup dalam rumah tangga dan sekaligus amanah yang diberikan oleh Allah untuk dididik menjadi dewasa dan berbudi luhur ${ }^{41}$.Hakekat manusia adalah memiliki kecenderungan kepada kebaikan ${ }^{42}$ Kecenderungan inilah yang menyebabkan bahwa peserta didik dalam proses pendidikannya harus diarahkan perkembangannya agar memiliki akhlaq al-karimah, baik vertical maupun horizontal sesuai dengan potensi atau tabi'at dasarnya tersebut. Peserta didik dalam proses pendidikannya harus berusaha untuk memiliki akhlak al-karimah dan senantiasa mengembangkan potensi yang dimilikinya dengan seperangkat ilmu pengetahuan sesuai dengan nilai-nilai kemanusiaan yang telah dianugerahkan Allah melalui firmanNya. Untuk mencapai maksud tersebut, maka

\footnotetext{
${ }^{40}$ Fathiyah Hasan Sulaiman, Sistem Pendidikan Versi al-Ghazali. terj. Fathur Rahman, (Bandung, al-Ma'arif, 1986), 24

${ }^{41}$ HAMKA, Lembaga Hidup., 223

${ }^{42}$ HAMKA, Tafsir Al-Azhar, Juz IX, (Jakarta, Pustaka Panjimas, 1999), 157
} 


\section{Zubaidah}

HAMKA mengingatkan kepada peserta didik dalam mengikuti prosess pendidikan diharapkan memiliki sikap dan etika.

Iqbal menekankan bahwa hanya manusia yang dapat melaksanakan pendidikan. Oleh karenanya, pendidikan harus dapat memupuk sifat-sifat individualitas manusia agar menjadi menjadi manusia sempurna ${ }^{43}$ Dalam mengemukakan pendapatnya tentang peserta didik, Iqbal memberikan kriteria kewajiban atau sifat yang harus dilakukan atau dimiliki peserta didik jika mereka ingin berhasil dalam kehidupannya dan mencapai tujuan pendidikan dengan gemilang. Kewajiban atau sifat tersebut adalah: (1) Motivasi tinggi dan bekerja keras, (2) Harus mempunyai rasa percaya diri yang kuat dan tidak bergantung pada orang lain, (3) Harus mempunyai rasa saling mencintai terhadap sesama, (4) Harus selalu taat pada peraturan yang ada, dan (5) Harus mempunyai sifat berani dan menghindari rasa takut .

Sementara itu HAMKA dengan lebih detail mengemukakan bahwa peserta didik harus memiliki sikap rendah hati kepada setiap orang yang menjadi pendidiknya termasuk dalam hal ini orang tuanya. Walaupun dalam perjalanannya peserta didik telah memiliki seperangkat ilmu pengetahuan dan kedudukan yang tinggi, namun hendaklah ia tetap memiliki sikap rendah hati dan menunjukkah akhlaq al karimah ${ }^{44}$. Sikap dan perilaku yang demikian akan berdampak terhadap proses humanisasi serta penghormatan yang disertai dengan pengabdian peserta didik kepada para pendidiknya, baik kepada kedua orang tuanya, para pendidik maupun al-KhaliqNya. Lebih jauh lagi HAMKA mengemukakan agar berhasil dalam pendidikan, maka peserta didik harus memiliki: (1) etika dalam proses pembelajaran agar proses belajar yang dilakukannya dapat berjalan secara efektif sehingga mampu menghantarkan peserta didik kearah tujuan yang diidealkan yaitu memiliki ilmu yang luas, sehingga menjadikannya mengetahui Tuhan dan memiliki budi pekerti yang mulia ; (2) etika kepada pendidik

Lingkungan/milieu mempunyai peranan yang sangat penting terhadap keberhasilan pendidikan, karena perkembangan jiwa anak itu sangat dipengaruhi oleh keadaan lingkungannya. Lingkungan dapat memberikan pengaruh yang positif dan pengaruh yang negative terhadap pertumbuhan dan perkembangan

${ }^{43}$ Danusiri, Epistemologi dalam Tasawuf Iqbal, (Yogyakarta, Pustaka Pelajar, 1996), 134

${ }^{44}$ HAMKA, Tafsir Al-Azhar, Juz IX, (Jakarta, Pustaka Panjimas, 1999), 41 
jiwa anak, sikapnya, akhlaknya, dan perasaannya. Lingkungan adalah seluruh yang ada, baik manusia maupun benda buatan manusia, atau alam yang bergerak, kejadian-kejadian atau hal-hal yang mempunyai hubungan dengan seseorang 45 Muhammad Iqbal berpendapat bahwa dalam interaksinya dengan lingkungan, manusia sebagai makhluk individu akan mengalami berbagai perubahan dinamis. Oleh karena itu, pendidikan harus dapat mengarahkan pertumbuhan dan perkembangan individu secara optimal. Terkait hubungan peserta didik dengan lingkungannya, Iqbal menyatakan bahwa: ..."Kehidupan ego merupakan semacam tantangan yang timbul karena adanya desakan dari ego yang merembes mempengaruhi lingkungan serta desakan dari lingkungan yang merembes mempengaruhi ego"46

Hubungan yang erat dan berlangsung timbal balik antara ego dan lingkungan perlu dipertahankan dan dimanfaatkan untuk kepentingan pendidikan. Melalui proses saling menerima, saling memberi, dan saling mempengaruhi antara individu dan lingkungannya yang beraneka ragam, dengan jalan mengadakan hubungan yang intensif dan bermanfaat dengan kenyataan sekitarnya sebanyak mungkin, maka individu dapat memperoleh dan meningkatkan kekayaan batin serta keberadaan insaniahnya.

Perkembangan individualitas peserta didik merupakan suatu proses yang kreatif, selalu mengadakan aksi dan reaksi yang bertujuan terhadap lingkunganya. Proses yang dimaksud bukan suatu kejadian dimana individu hanya tinggal menyesuaikan diri (dalam arti mengikuti begitu saja) secara pasif terhadap lingkungan statis. Sehingga hakikat lingkungan sangat menguntungkan bagi tumbuh kembangnya diri. Perkembangan individu menurut Iqbal mengimplikasikan individu harus mengembangkan kekayaan batin dan eksistensinya ${ }^{47}$. Mengembangkan pribadi merupakan hasil interaksi dengan lingkungan dan hanya dengan jalan demikian ia dapat meningkatkan dirinya di atas lingkungannya. Kontak dengan lingkungan itu yang memberikan stimulasi yang besar kepadanya dan dengan jalan itulah peserta didik mempertajam

\footnotetext{
45 Dirjen Binbaga Islam, Ilmu Pendidikan Islam, (Jakarta, Dirjen Binbaga, 1984), 61

${ }^{46}$ Muh.Iqbal, The Development of Metaphysucs in Persia: A Contribution to The History of Muslim Philosophy (Metafisikan Persia Suatu Sumbangan Untuk Sejarah Filsfat Islam).diterjemahkan Jobar Ayoeb, (Bandung, Mizan, 1995), 82

${ }^{47}$ Muhammad Iqbal, The Recontructioan in Religious Thouht in Islam (Membangun Kembali Alam Pikiran Islam), diterj. Ustman Salibi, (Jakarta, Bulan Bintang, 1996), 112-113
} 


\section{Zubaidah}

inteleknya, membina peradabannya dan terbuka baginya berbagai kemungkinan yang luas untuk mencapai keberhasilan dalam kedudukannya di tengah lingkungannya.

HAMKA melengkapi pendapat Muhammad Iqbal diatas dengan mengemukakan bahwa lingkungan yang dominant mempengaruhi proses pendidikan peserta didik ialah lingkungan keluarga, lingkungan sekolah dan lingkungan masyarakat

Keluarga bahagia dan sejahtera yang dijiwai oleh pancaran sinar tauhid tidaklah bagitu saja tercipta dengan sendirinya, tetapi harus melalui proses sosialisasi, sehingga nilai-nilai universal dari tahuid itu menjadi miliki keluarga sosialisasi menunjuk pada semua factor dan proses yang membuat setiap manusia menjadi selaras dalam hidup ditengah-tengah orang lain. ${ }^{48}$ Sementara itu keluarga harmonis dalam pandangan HAMKA adalah suatu keluarga dimana para penghuninya mampu berkomunikasi secara efektif, masing-masing memiliki kesadaran yang tinggi akan hak dan kewajibannya ${ }^{49}$ Ayah, ibu dan anak menyadari hak dan kewajibannya masing-masing. Relasi antara bapak, ibu dan anak serta anggota keluarga lain dalam keluarga harus berlangsung secara dialogis dan demokratis, dengan didasari oleh sikap saling percaya ${ }^{50}$ Sikap dan perilaku orang tua juga menjadi factor yang signifikan mempengaruhi bagi pembentukan kepribadian anak. Sikap dan perilaku ini berkait dengan cara bicara dan cara berfikir, serta cara bertindak orang tua baik di dalam maupun di luar rumah.Orang tua harus memiliki sikap dan perilaku yang adil, terhadap anak-anaknya.HAMKA memandang bahwa sikap adil ini menjadi aksentuasi dari berbagai perilaku yang harus dilakukan oleh orang tua kepada anak-anaknya. Hal demikian disebabkan betapa pentingnya orang tua menegakkan keadilan dalam berbagai sendi kehidupan keluarga. Disamping itu, sikap dan perilaku orang tua yang terpuji maupun tercela juga akan berpengaruh terhadap perkembangan kepribadian anak

HAMKA mensyaratkan seseorang yang akan menjadi pendidik harus berperangai baik dan membersihkan diri dari berbagai perilaku yang tercela ${ }^{51}$,

\footnotetext{
48 M.Enoch, Markum, Sosialisasi: Hasil Seminar Penelitian Kebudayaan, (Jakarta, Pen.Direktorat Sejarah dan Nilai Tradisional, Direktorat Jendral Kebudayaan Departemen Pendidikan dan Kebudayaan, 1983), 1

${ }^{49}$ HAMKA, Lembaga Hidup., 218

50 Ibid, 219

51 HAMKA, Lembaga Hidup., 253
} 
karena secara psikologis anak pada usia sekolah memiliki sifat imitative (suka meniru pada orang yang dipandang dapat menjadi panutan), dan salah satu figure yang menjadi obyek sifat imitative tersebut adalah pendidik di sekolah. Semua sikap dan tingkah laku yang dilakukan oleh pendidik di sekolah akan menjadi cermin bagi perilaku peserta didiknya. Oleh karenanya pendidik dituntut untuk menjadi contoh yang baik bagi para peserta didiknya. Pendidik ibarat pemimpin bagi peserta didiknya. Sebagai seorang pemimpin, pendidik diharapkan mampu menjadi panutan serta tauladan dalam semua perilaku kepemimpinannya.

Terdapat hubungan dan keterkaitan yang sangat erat antara masyarakat dan pendidikan, bersifat korelatif malahan bersifat mutual simbiosis. Kenyataan di lapangan bahwa masyarakat yang kurang memperhatikan perkembangan dunia pendidikan akan terbelakang; sebaliknya masyarakat yang baik, maju, modern adalah masyarakat yang didalamnya ditemukan suatu tingkat pendidikan yang baik, maju dan modern pula. Dalam konteks ini HAMKA menekankan adanya hubungan yang sinergis antara sekolah dan masyarakat dalam rangka melaksanakan proses pendidikan ${ }^{52}$.

Lingkungan masyarakat yang secara signifikan sangat berpengaruh terhadap pendidikan peserta didik adalah adat istiadat dan suasana kehidupan yang terjadi dalam lingkungan masyarakat ${ }^{53}$. Menurut HAMKA, agar adat istiadat dapat berpengaruh terhadap perkembangan kepribadian anak, maka adat istiadat tersebut harus dibangun diatas nilai-nilai agama yang benar; dengan redaksi berbeda Muhammad Iqbal mengatakan bahwa hanya akan memahami pertautan yang sebenarnya antara potensi-potensi insani dengan lingkungan social yang menguntungkan itu apabila disertai kesadaran akan peranan peradaban dan kebudayaan. Kesadaran ini yang dengan penuh pertimbangan mengadakan seleksi tentang berbagai kecenderungan serta disposisi tertentu, mana yang hendaknya dipupuk dan dikembangkan dan mana yang tidak ${ }^{54}$

Dari pendapat Muhammad Iqbal dan HAMKA diatas dapat disimpulkan bahwa keduanya sependapat bahwa tanpa adanya interaksi antara kedua

\footnotetext{
52 Ibid, 248

53 Ibid, 142

54 KG.Saiyidain, Iqball's Eductioon Philosophy (Percikan Filsafat Iqbal Mengenai Pendidikan), alih Bahasa MI Soelaeman, (Bandung, CV Diponegoro, 1981), 145
} 


\section{Zubaidah}

belah pihak (lingkungan dengan individu) maka mustahil seseorang dapat berkembang dan tumbuh dengan sewajarnya.

Jenis metode pengajaran yang dikehendaki Iqbal ialah yang menghadapkan peserta didik pada situasi baru dan masalah baru yang mengundang peserta didik untuk bekerja dengan penuh kesadaran akan tujuan yang digalinya dari sumber yang tersedia dalam lingkungan mereka..

Iqbal menawarkan berbagai macam metode pengajaran yang tepat untuk mencapai tujuan kurikulum, dimana metode pengajaran ini tidak boleh serba kaku, karena memberikan kemungkinan menghilangkan inisiatif, melahirkan tindakan yang mungkin kurang tepat atau perbuatan salah dalam bidang intelektual, dan menghilangkan kemungkinan untuk dapat belajar dari kekurangan dan kesalahan. Tujuan diadakan metode ialah menjadikan proses dan hasil belajar mengajar berdaya guna dan berhasil guna dan menimbulkan kesadaran peserta didik untuk mengamalkannya melalui teknik motivasi yang menimbulkan gairah belajar peserta didik secara mantap. Fungsi metode adalah mengarahkan keberhasilan belajar, memberi kemudahan kepada peserta didik untuk belajar berdasarkan minat, serta mendorong usaha kerja sama dalam kegiatan belajar mengajar antara pendidik dengan peserta didik. Iqbal lebih mengutamakan corak metode yang terbuka lebar bagi keaktifan sendiri serta belajar melalui perbuatan. Adapun metode yang ditawarkan oleh Iqbal antara lain: Metode eksperimental, metode proyek, metode trial and error dan metode problem solving.

Sementara HAMKA memberikan alternative yang lain; menurut beliau setidaknya ada tiga pendekatan dalam pendidikan yaitu: dalam pendidikan yaitu: (1) al-Hikmah, yaitu bahwa proses pendidikan harus dilakukan dengan cara yang bijaksana, menggunakan akal budi yang mulia, dada yang lapang, hati yang bersih, serta menarik perhatian peserta didik. Pendekatan al-Hikmah ini menuntut adanya konsistensi antara ucapan, tindakan dan sikap dengan pandangan hidup, dalam setiap pelaksanaan proses pendidikan, (2) al-Mau'izhah Hasanah, yaitu bahwa suatu proses pendidikan memerlukan kelemah lembutan dan kehalusan dalam bertutur kata, agar pesan-pesan dapat terkomunikasikan secara efektif , (3) Jadilhul Billati hiya ahsan, yaitu bahwa proses pendidikan harus dilakukan secara dialogis, yang dalam pelaksanaannya selalu memperhatikan prinsip-prinsip 
persamaan, kesetaraan, demokratis dan rasional ${ }^{55}$ Beberapa metode yang dapat digunakan dalam melaksanakan proses pendidikan yaitu metode penteladanan, metode pembiasaan, metode diskusi, metode hukuman dan ganjaran.

\section{KESIMPULAN}

Berdasarkan atas paparan sebelumnya terkait dengan Konsep Pendidikan menurut Muhammad Iqbal dan HAMKA dapat disimpulkan, pertama; Dimata Iqbal, pendidikan adalah bagian tak terpisahkan dari peradaban manusia. Bahkan, pendidikan sekaligus menjadi substansi dari peradaban manusia. Pendidikan bukan proses mengajar atau belajar semata karena kegiatan ini dianggap berlangsung secara sederhana atau mekanistis, dan hanya berlangsung diantara empat dinding sekolah. Pendidikan dalam pengertian sempit ini tidak mampu mencakup pembinaan yang dapat membentuk, mengembangkan dan memodifikasi gagasan dan perbuatan perorangan atau kelompok. Iqbal berpendapat bahwa pendidikan harus dipandang sebagai suatu keseluruhan daya budaya yang mempengaruhi kehidupan perorangan maupun kelompok masyarakat. Dalam rangka melaksanakan gagasan rekonstruksinya, Iqbal mengemukakan pandangannya tentang pendidikan, yaitu : (1) Konsep Individu, (2) Pertumbuhan Individu, (3) Keseimbangan Jasmani dan Rohani, (4) Pertautan individu dan Masyarakat, (5) Kreativitas Individu, (6) Peran Intelektual dan Intuisi, (7) Pendidikan Watak, dan (8) Pendidikan Sosial.

Model pemikiran Muhammad Iqbal mengenai pendidikan jika dipahami akan berimplikasi bahwa pendidikan seharusnya bersifat Islami yang dinamis, kreatif dan diarahkan untuk memupuk dan memberikan kesempatan gerak kepada semangat kreatif yang bersemayam dalam diri manusia, disamping mempersenjatainya dengan kemampuan untuk menguasai bidang seni, dan ilmu pengetahuan baru, kecerdasan dan kekuatan. Yakni corak system pendidikan yang mempersiapkan peserta didik agar berkehidupan secara islami, aktif dan kreatif, bukan corak system pendidikan yang lebih mengutamakan perenungan pasif.

Kedua; HAMKA membedakan makna pendidikan dan pengajaran. Kedua kata tersebut (pendidikan dan pengajaran) merupakan suatu sistem yang saling berkaitan. Dalam pelaksanaannya, baik pendidikan maupun pengajaran hendaknya diformat secara sistematis, sesuai dengan dinamika fitrah, diferensiasi peserta didik dan

55 HAMKA, Tafsir Al-Azhar, Juz XIII-XIV, (Jakarta, Pustaka Panjimas, 2000), 321 


\section{Zubaidah}

tuntutan perkembangan zaman. Peserta didik seyogyanya dibawa dalam situasi pendidikan secara demokratis. Dengan pola ini, peserta didik dapat lebih leluasa mengekspresikan seluruh potensi yang dimilikinya. Pelaksanaan pendidikan dan pengajaran yang tidak mempertimbangkan aspek peserta didik sebagai obyek dan subyek didik yang dinamis dan merdeka, akan membuat pelaksanaan pendidikan berjalan secara pasif serta telah meletakkan peserta didik dalam posisi statis.

Model pemikiran HAMKA bahwa proses pendidikan tidak hanya berorientasi pada hal-hat yang bersifat material belaka. Pendekatan yang demikian itu tidak akan dapat membawa manusia kepada kepuasan batin (rohani). Format pendidikan yang harmonis dan integral, merupakan karakteristik pendidikan Islam yang Ideal dan efektif dalam mencapai tujuan yang diinginkannya yaitu terciptanya peserta didik yang berkepribadian insan kamil, Karakteristik tersebut meliputi : (1) penekanannya disamping pada aspek social, individual, budaya, politik, ekonomi juga pada aspek ibadah dan akhlaq al -karimah, (2) adanya pengakuan pada potensi (fitrah) manusia, baik secara fisik maupun psikis yang diharmonisasikan secara integral dalam melihat peserta didik sebagai khalifah dan makhluk Allah di muka Bumi, (3) pendidikan hendaknya menekankan pada tumbuhnya rasa tanggung jawab pada diri peserta didik, baik terhadap dirinya, masyarakat, alam semesta maupun kepada Allah

\section{DAFTAR PUSTAKA}

Abdul Wahab 'Azzam, Iqbal: Siratuh wa Falsafatuh wa Syi'ruh (Filsafat dan Puisi Iqbal), diterjemahkan oleh Ahmad Rofi' Usman, (bandung, Pustaka Husna, tt)

Abu A'la al Maududi, Manhaj Jadid I Tarbiyah wa Ta'lim, terj. Judi al Falasani, (Solo, CV Ramadani, 1991).

Abul Hasan al -Nadwi, Pendidikan Islam yang Mandiri, alih bahasa Afifi Muhammad, (Bandung, Dunia Ilmu, 1987)

Ahmad D Marimba, Pengantar Filsafat Pendidikan, (Bandung, al-Ma'arif, 1989)

Ahmad Tafsur, Ilmu Pendidikan dalam Perspektif Islam, (Bandung, Remaja Rosdakarya, 1992).

Arifin HM, Kapita Selekta Pendidikan Islam dan Umum, (Jakarta, Bina Aksara, 1991).

Danusiri, Epistemologi dalam Tasawuf Iqbal, (Yogyakarta, Pustaka Pelajar, 1996)

Dawan Rahardjo (peny), Insan Kamil: Konsep Manusia menurut Islam, (Jakarta, Temprint, 1989)

Dirjen Binbaga Islam, Ilmu Pendidikan Islam, (Jakarta, Dirjen Binbaga, 1984)

Fadlil al Jamali, Menerobos Krisis Pendidikan Dunia Islam, terj.Muzayin Arifin, (Jakarta, Golden Terayon Press 1988)

Fathiyah Hasan Sulaiman, Sistem Pendidikan Versi al-Ghazali. terj. Fathur Rahman, (Bandung, al-Ma'arif, 1986)

Fazlur Rahman, Islam dan Modernitas: Tentang Transformasi Intelektual, alih bahasa Ahsin Mohammad, (Bandung, Pustaka, 1995) 
Fuad Amsari, Islam dalam Dimensi Pembangunan Nasional, (Surabaya, PT BIna Ilmu, 1989)

HAMKA, Lembaga Budi, (Jakarta, Pustaka Panjimas, 1983)

HAMKA, Lembaga Hidup, (Jakarta, Pustaka Panjimas, 1983)

HAMKA, Tafsir Al-Azhar, Juz IX, (Jakarta, Pustaka Panjimas, 1999)

HAMKA, Tafsir Al-Azhar, Juz XIII-XIV, (Jakarta, Pustaka Panjimas, 2000)

HAR.Tilaan, Manajemen Pendidikan Nasional Kajian Pendidikan Masa Depan, (Bandung, PT Remaja Rosdakarya, 1994)

Hasan Langgulung, Azas-azas Pendidikan Islam, (Jakarta, Radar Jaya Ofsett, 1987)

Ismail Haqi al-Barusawi dalam Abdul Mujib, Ilmu Pendidikan Islam, (Jakarta, Kencana Prenada Media, 2006)

Ismail Raji al Faruqi, Islamisasi Ilmu Pengetahuan: Prinsip-prinsip dan Rencana Kerja, terj.Anas Mahyudin, (Bandung, Pustaka, 1984)

KG.Saiyidain, Iqball's Eductioon Philosophy (Percikan Filsafat Iqbal Mengenai Pendidikan), alih Bahasa MI Soelaeman, (Bandung, CV Diponegoro, 1981)

M.Enoch, Markum, Sosialisasi: Hasil Seminar Penelitian Kebudayaan, (Jakarta, Pen.Direktorat Sejarah dan Nilai Tradisional, Direktorat Jendral Kebudayaan Departemen Pendidikan dan Kebudayaan, 1983)

Machnun Husein, Pendidikan Islam dalam Lintasan Sejarah, (Yogyakarta, Nur Cahya, 1983)

Miss Luce-Calude Maitre, Pengantar ke Pemikiran Iqbal, alih bahasa Djohan Efendi, (Bandung, Mizan, 1992)

Muh.Iqbal, The Development of Metaphysucs in Persia: A Contribution to The History of Muslim Philosophy (Metafisikan Persia Suatu Sumbangan Untuk Sejarah Filsfat Islam).diterjemahkan Jobar Ayoeb, (Bandung, Mizan, 1995)

Muhammad Fadhil al-Jamali, Filsafat Pendidikan dalam al-Qur'an,terj. Judial Falasani, (Surabaya, Bina Ilmu, 1986)

Muhammad Iqbal, Javid Namah, diterj. Dr.Mohammad Sadikin, (Jakarta, Pustaka Panti Mas, 1987)

Muhammad Iqbal, The Recontructioan in Religious Thouht in Islam (Membangun Kembali Alam Pikiran Islam), diterj. Ustman Salibi, (Jakarta, Bulan Bintang, 1996)

Mushthafa al-Maraghi, dalam Abdul Mujib, Ilmu Pendidikan Islam, (Jakarta, Kencana Prenada Media, 2006)

Naquib al-Attas, Islam dan Sekularisme, (Bandung, Pustaka Setia, 1980)

Salahuddin al-Nadwi, Muhammad Iqbal wa Qadaya al-Tajdid, (Studia Islamika, Vol.II. No.I, 1995)

Suyuthi Pulungan dalam Abdullah Idi, Revitalisasi Pendidikan Islam, (Yogyakarta, Tiara Wacana, 2006)

Agus Hakim, Kulliyatul Mubalighien Muhammadiyah dan Buya HAMKA, Kenangkenangan 70 Tahun Buya HAMKA, (Jakarta, Yayasan Nurul Islam, 1978) 